\title{
MOLLUSCS AND THE HISTORICAL GEOGRAPHY OF NORTHEASTERN SUMATRA IN THE EIGHTH CENTURY A.D.
}

\author{
0. W. Wolters
}

The toponym Shêng-têng appears in the account of a maritime itinerary from Canton to India, compiled by Chia Tan about A.D. 800 out of information brought to China by envoys and merchants. 1 Shêng-têng is unambiguously identifiable as part of the northeastern coast of Sumatra; in terms of the itinerary's estimate of the duration of the voyage through the Straits of Malacca, it would have been situated rather more than halfway between the southern entrance to the Straits and the northern tip of the island. ${ }^{2}$ As early as 1904 Pelliot suggested that the toponym might refer to the region of Deli and Langkat. ${ }^{3}$ But the meaning of the word has not, to the best of my knowledge, been established.

According to Karlgren's Grammata Serica Recensa, the T'ang pronunciation of Shêng-têng was Sị̀ng-d'əng. ${ }^{4}$ The $S$ is a voiceless palatalsibilant. By that time the voiced $d$ may already have been unvoiced and represented a $t$. The first syllable ends with $n g$, but the interchange of $n$ and $n g$ as the final nasal was fairly widespread in Chinese dialects

${ }^{1}$ I would not have written these pages without the expertise of Professor John McCoy and Mr. Mathew Charles, whose assistance I gratefully acknowledge. I also wish to thank Mr. E. Edwards McKinnon for information about northeastern Sumatra. Mr. McKinnon is a resident of the area who is actively interested in local archaeological work. Chia Tan's itinerary is in the Hsin T'ang-shu (Po-na edition; Shanghai: Commercial Press, 1936), ch. 43C, 18b. Translations of the relevant section are available in Paul Pelliot. "Deux itinéraires de Chine en Inde à la fin du VIIle siècle," Bulletin de l'École Française d'Extrême-Orient, IV, 1-2 (1904), pp. 372-73; Wang Gungwu, "The Nanhai Trade," Journal of the Malayan Branch of the Royal Asiatic Society (hereafter JMBRAS), XXXI, 2 (1958), p. 105; 0. W. Wolters, Early Indonesian Commerce (Ithaca: Corne11 University Press, 1967), pp. 187-88.

2The itinerary mentions a "strait" that ships entered after crossing the South China Sea. I believe that this strait is not the Straits of Malacca but the Strait of Singapore at the point where it narrows to about ten miles in width between Singapore Island and the Batam and Bulang islands. It is said to be a hundred $l_{i}$ in length, or approximately thirty miles. The details of the itinerary imply that the strait was the last lap of the voyage from the coast of southern vietnam on an unaltered course that Chinese sailing conventions regarded as sailing from "north" to "south." Ships entered the Straits of Malacca only after leaving the strait and heading "west" or, as we would say, northwest. The T'ang sound of the strait's name is T'ínet, which can hardly be a transcription of sélat, the Malay word for "strait." Chia Tan was probably using a truncated form of Sĕlat Tśiět, a name that I cannot satisfactorily restore.

3Pe11iot, "Deux itinéraires," p. 354.

4B. Karlgren, Grammata Serica Recensa (reprint edition; Stockholm: Museum of Far Eastern Antiquities, 1964). 


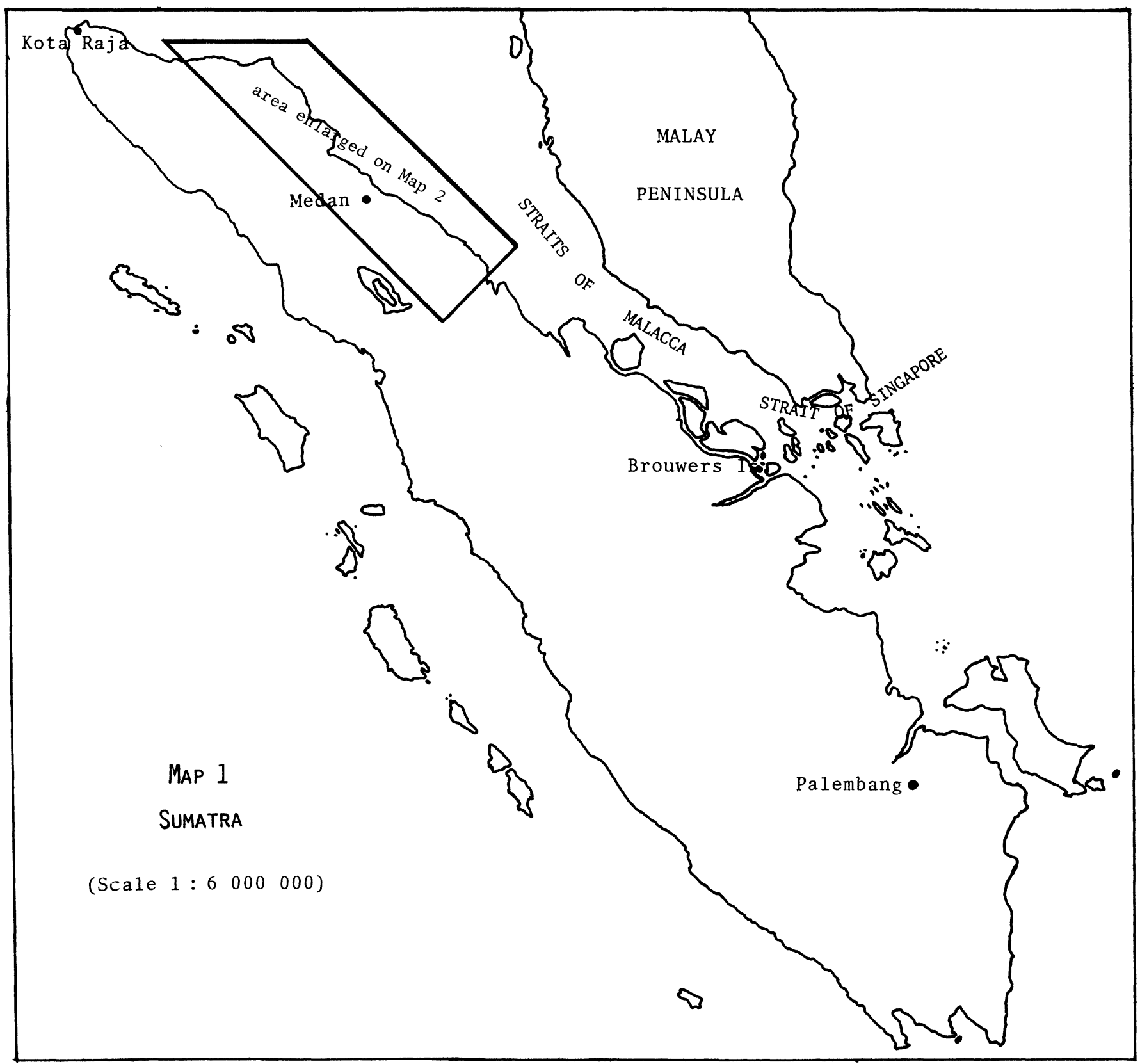




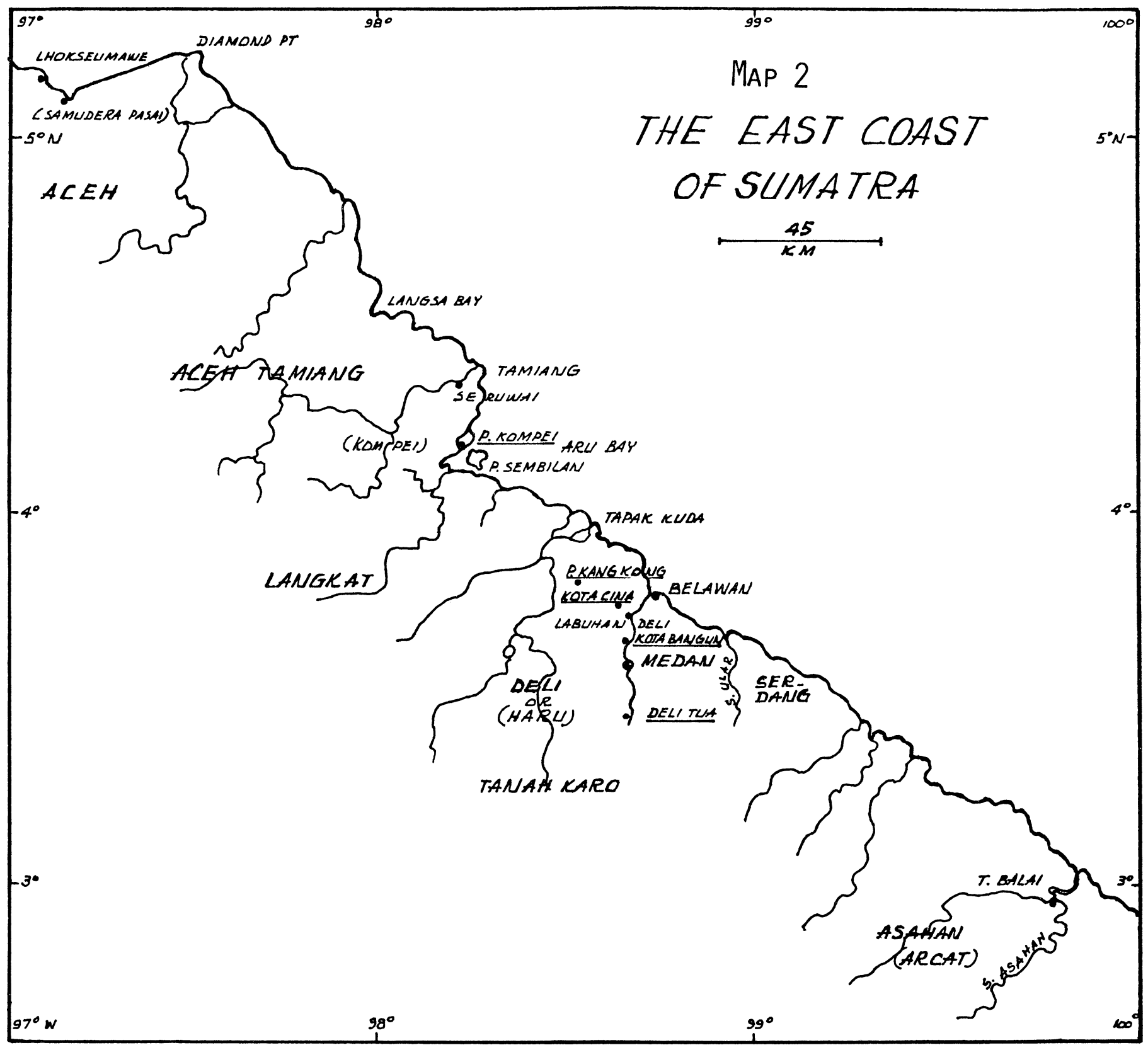

SUNG PERIDD CERAMICS SITES UNDERLINED 
during $\mathrm{T}^{\prime}$ ang times.5 Chia Tan's transcription may therefore be based on a non-Chinese word that resembled "sinting," "senteng," "sinding," or "sendeng." Since Chinese ships did not sail to the Indonesian archipelago in the eighth century, and foreigners were thus responsible for making place-names there known in China, Shêng-têng's position on the Straits of Malacca permits us to suppose that a Malay word was being transcribed as S $j_{i}$ əng-d'əng.

The place in question may have been a small coastal and trading kingdom, but no tributary missions were ever registered under this name. Indeed, no other available source mentions it. Moreover, Chia Tan describes it as a chou. No less than a dozen kuo, or "kingdoms," appear in the Southeast Asian portion of the itinerary but only four chou, including this one. As Pelliot pointed out in 1904 , chou is the equivalent of the Sanskrit dvipa, or "island," and is also used to refer to coastal terrain. ${ }^{\circ}$ A geographical rather than a political usage of the term is illustrated by the other three Southeast Asian chou mentioned in the itinerary: Pānduranga chou, Ho-ling chou, and Chia-lan chou. In each case the context shows that foreigners were referring to geographical regions. Pānduranga chou refers to a stretch of the central and southern coast of what is now the Socialist Republic of Vietnam and in earlier times (eighth century) was one of several Chamspeaking regions on that coast which were frequent1y autonomous from their neighbors.7 The Chinese knew the political center closest to Pändụungana as Huan-wang, described by Chia Tan as a "kingdom." An even clearer example of the geographical significance of chou is the itinerary's reference to Ho-ling chou. Ho-ling is described as "the largest island (chou) in the south" and is also described as a "kingdom." The island in question is Java. Finally, Chia-1an (Ka-lâm) chou in the Indian Ocean is described as "Chia-1an chou of $P^{\prime} O$ [B'uâ] kingdom." Pelliot was inclined to believe that this name referred to the Nicobar islands, casually associated by traders with the P'o country. P'o is probably an abbreviation of $P^{\prime} \mathrm{O}-1 \mathrm{u}$ [B'uâ-1uo], the toponym that appears in the itinerary immediately before Chia-lan and means "Barus," which I continue to identify with the neighborhood of Kota Raja. ${ }^{8}$ The consistent usage of chou in the itinerary therefore justifies the conclusion that Shêng-têng was the name of a stretch of the northeastern coast of Sumatra and not of a kingdom or port.

5 I am grateful to Professor McCoy for this information.

6Pelliot, "Deux itinéraires," p. 353, n. 2.

7Professor Boisselier notes how regionalism helped to preserve Cham culture from extinction in the face of Vietnamese expansion southward; Jean Boisselier, La statuaire du Champa, recherches sur les cultes et l'iconographie (Paris: Ecole Française d'Extrême-Orient, 1963), p. 405.

8Wolters, Early Indonesian Commerce, pp. 187-93. In a conversation on September $24,1976, \mathrm{Mr}$. McKinnon informed me that a recent archaeological reconnaissance of the northern coast of Sumatra has revealed the presence of pre-Moslem antiquities. Perhaps before long something will become known of the material remains, including foreign trade debris, at and near the center known to the Arabs as Rāmn $\bar{i}$ and to Tomé Pires as Lambry, toponyms that I associate with the "Barus" port mentioned in $T$ 'ang Chinese sources; on these references see Wolters, ibid., pp. 192-95. 
I suggest that Śìng-d'əng (Shêng-têng) is a transcription of "sinting" or "senteng," which is the Malay word in Johore and Riau for two kinds of bivalve molluscs: Placuna placenta, Linn., and Placuna selia, Lam. ${ }^{\circ}$ The molluscs are found in tidal flats and chiefly in the neighborhood of estuaries just below low tide leve1.11 The reconstruction of the transcription is not absurdly improbable. "Tiram" (oyster) is a fairly common place-name in Sumatra and the Malay Peninsula, and there is a Tanjong Tiram in the Deli region.12 A more convincing reason for the identification is that Placuna molluscs happen to be a prominent feature of marine life on the Sumatran coast at least between Kompei island and Deli. A few placuna placenta shells have been found in a prehistoric midden inland from this coast. ${ }^{13}$ In 1823 Anderson was impressed by "the great variety of shellfish in the Deli

9The other and unlikely possibility is "sinding" or "sendeng," which means "leaning or heeling over to one side"; R. J. Wilkinson, A MaLay-EngZish Dictionary (Singapore: Kelly and Walsh, 1903), p. 414. Modern maps show a village of Sentang near Kuala Batu Bara. In the 1820s John Anderson reported a Sintang on the Tanah Datar tributary and also a Santang on the neighboring Lima Laras river; John Anderson, Mission to the East Coast of Sumatra in 1823 (Edinburgh and London: W. Blackwood, 1826), p. 312. I have rejected these possibilities because Chia Tan was referring to a coast and not to a specific trading center and also because the $T$ 'ang Chinese would have used a different character for the second syllable of the word if they had wanted to reproduce an a vowel.

${ }^{10} \mathrm{I}$. H. Burkill, A Dictionary of the Economic Products of the Malay Peninsula (London: Crown Agents for the Colonies, 1935), II, p. 1764. Wilkinson (Malay-English Dictionary, p. 411) mentions only Placuna sella, but Burkill and Winstedt ascribe these names to both species of Placuna. See R. 0. Winstedt, An Unabridged MalayEnglish Dictionary, 2nd ed. (Singapore: Marican, 1957), p. 309. The following work translates "sinting" merely as "Placuna": G. L. Kesteven (ed.), Malayan Fisheries. A Handbook Prepared for the Inaugural Meeting of the Indo-Pacific Council, Singapore, March 1949 (Singapore: Malaya Pub. House, 1949), p. 79.

${ }^{11}$ Burkill, Dictionary, II, p. 1764. 12 Information from Mr. McKinnon.

${ }^{13} \mathrm{H}$. R. van Heekeren, The Stone-Age in Indonesia (The Hague: M. Nijhoff, 1957), p. 72. The site is a shell mound at Binjai-Tamiang, west of Medan, and is about 15 kilometers inland and 10 meters above the present sea level. Figure 14 on p. 70 of van Heekeren's book supplies a useful map of the span of shell middens in this region known to the author. The span covers a stretch of approximately 130 kilometers and is now from 10 to 15 kilometers inland. For a recent report on some of these middens, see E. Edwards McKinnon, "A Brief Note on the Current State of Certain of the Kitchen Middens of East Sumatra," Berita Kajian Sumatera, IV, 2 (1975), pp. 45-50. In a conversation on September 24, 1976, Mr. McKinnon suggested that shell middens were so" numerous in some coastal areas of northeastern Sumatra that the implication must be that in early times the local economy depended to an important extent on shellfish, even though the predominant species so far found in the middens is not Placuna. Meretrix meretrix, Linn., is a more prominent mollusc in the prehistoric midtens of northeastern Sumatra and has also been excavated from the Province Wellesley middens on the opposite side of the Straits; M. W. F. Tweedie, "The Stone Age in Malaya," JMBRAS, XXVI, 2 (1953), p. 67. Meretrix meretrix was probably a more important article of food than Placuna placenta. Burkill (Dictionary, II, p. 1455) quotes Tweedie as stating that Meretrix meretrix is "sold extensively in the fish-markets." On this mollusc as an article of diet on the Sumatran coast, see J. C. van der Meer Mohr, "Miscellanea Zoologica Sumatrana: XVIII. Note préliminaire sur la composition conchyliologique d'un amas préhistorique de coquelles près de Medan (Sumatra)," De De $i$ Courant, June 1927 (date unknown). 
area,"14 and Stead, a fisheries expert reporting on Belawan and Medan in 1923, was "astonished at the very large numbers [of Placuna placenta] which were being taken on the extensive flats lying off the mouth of the river."15 Mr. McKinnon has sent me photographs that show that the Kompei beaches, some way north of Deli, are covered with shells. Professor Emeritus We11s, of Corne11 University, has examined the photographs and identifies these shells as being those of Placuna placenta, with their "quite flat valves."16

Finally, we can note that the profusion of shellfish on this part of the Sumatran coast is reflected in a legend in the oral history of Kota China near Deli. The legend relates that there was once an Indian settlement at the edge of the sea here. Chinese then occupied it. But the Chinese settlement "was overrun by a plague of shellfish that came up out of the sea. The shells got into every kind of hole there was, into their [the Chinese] eyes, their noses, then ears and mouths. The shells filled their cooking pots and rice bowls until the Chinese could stand it no more and they too ran away."17

On these grounds I propose as a hypothesis that Shêng-têng (Śiongd'əng) should be restored as "sinting" or "senteng," meaning the P̂िacuna molluscs, and that the word was used as a name for a strip of coast that included at least the coast between Kompei island and the Deli area. ${ }^{18}$

Who may have known this part of the coast as the "mollusc coast"? According to Wilkinson, "sinting" or "senteng" is the word as it is pronounced in Johore and Riau, though in Kedah, on the opposite side of the Straits, the word is pronounced as "siting."19 The $i$ sound in

\footnotetext{
${ }^{14}$ Anderson, Mission, pp. 48, 252, 288. On p. 252 he refers to Pulau Berting Tinggi, where "there is a great abundance of shell-fish procurable. This island forms a good landmark for entering the Delli [sic] and Bulu China rivers, and on making the coast."

15David G. Stead, General Report upon the Fisheries of British Malaya with Recommendations for Further Development (Sydney: A. J. Kent, 1923), p. 280. Stead notes that "one only sees the animal (fleshy) portion for sale in the markets, but in very great numbers." I do not understand why Stead's information about the prominent use of Placuna placenta for food is not reflected in the shell remains of the Binjai-Tamiang midden, mentioned in note 13 above.
}

${ }^{16}$ I am grateful to Professor John W. We1ls for his interpretation of the photographs. Professor Wells adds: "It is the common 'window-pane' she11 of Southeast Asia, commonly seen here made into wind chimes and similar kitsch objects." Placuna" placenta is described and illustrated in Tetsuaki Kira, Shells of the Western Pacific in Color (Osaka: Hoikusha, 1962), I, p. 133. The Chinese name for this shellfish is hai yüeh; Chang Hsi et al., Nan hai ti shuang $k^{\prime} O$ Zei juan t'i tung wu (Peking: K'ohsüeh, 1960), p. 90. "Hai yüeh" is mentioned in the 1249 revision of T'ang Shen-wei's materia medica of 1112 (Ch'ung hsiu chêng ho ching shih chêng lei pei yung pên ts'ao [Peking: Hsin-hua shu-tien, 1957], ch. 22, 456), but its Sumatran habitat is not noted.

17E. Edwards McKinnon and Tengku Luckman Sinar, "Kota China: Notes on Further Developments at Kota China," Berita Kajian Sumatera, IV, 1 (1974), p. 85.

${ }^{18} \mathrm{An}$ exploration of the fish fauna of the Rokan river mouth, some distance south of Medan, revealed only two kinds of mollescs, neither of which was Placuna; J. D. F. Hardenberg, "The Fish Fauna of the Rokan Mouth," Treubia, XIII (1931), p. 88.

19 Wilkinson, Malay-English Dictionary, p. 411. 
Malay is often pronounced $e(\hat{e})$ in the Deli area, 20 and the molluscs whose photographs were identified by Professor Wells as Placuna placenta are known locally as "seteng."21 I doubt whether means are available for establishing the dialect variations of the word in the eighth century in order to identify the Malays responsible for bringing the word to the notice of the Chinese. My surmise is that Malay pilots or crews, perhaps recruited from the offshore islands at the southern end of the Straits, invented the coast's nickname and brought it into currency. The inhabitants of the trading centers on the coast in question probably preferred to identify themselves as living in Kompei or "Bara" or in other settlements on the estuaries.22

The itinerary does not help us to estimate the expanse of the mollusc coast. Chia Tan ignores the Sumatran coast south of Sheng-têng until he mentions Fo-shih, or Sriviyaya in the neighborhood of Palembang. The reason for his silence is that the ships whose itinerary he is plotting approached the Sumatran coast from the eastern side of the Straits of Malacca. They had emerged from the Singapore Strait and avoided the predatory inhabitants of the Kât-kât tseng-t'si islands. These islands, mentioned by Chia Tan, have not been identified. If Pelliot is correct in supposing that they were connected with the Brouwers islands off the Sumatran coast, traders had every reason for sailing out at sea, for the residents of these islands were notorious for preying on sailing vessels. The early Ming sailing directions are similarly silent about the coast south of Aru, a place-name that Dr. Mills has convincingly identified with the Deli area, and the reason is that the Chinese ships in the fifteenth century usually approached the Sumatran coast from Malacca. 23

One early toponym, however, may be associated with the coast south of Deli, and its source is contemporary with Chia Tan's itinerary. The Hsin T'ang-shu's account of the Pyu kingdom in Burma mentions a large number of Southeast Asian places, some of which are certainly in the

${ }^{20}$ R. Roolvink, "'Dialek Melayu di Deli'. Berberapa tjatatan serta dengan sedjumlah tjeritera," Bahasa dan Budaja, III, 1 (1953), p. 6.

$21 \mathrm{Mr}$. McKinnon's letter to me, dated October 31, 1975.

22For Kompei's and P'o-10's tributary relationship with China in the seventh century, see 0. W. Wolters, The Fall of Srivijaya in Malay History (Ithaca: Cornel1 University Press, 1970), pp. 44-45. I still believe that the seventh century toponym P'o-1o (B'uâ-1a) may represent "Bara" (ibid., p. 196, n. 17), but I am no longer confident that the site is the present-day Batu Bara. Today, the ancient site of P'o-lo is probably inland as a result of the advancing coastline. According to van Bemmelen, "The coast of Deli and Assahan [sic], in northern Sumatra, in 1600 was about 15 to 30 miles more inland than in 1821 (according to Anderson), which means an average shift of the coast line of about $100 \mathrm{~m}$. per annum"; R. W. van Bemmelen, The Geology of Indonesia (The Hague: M. Nijhoff, 1949), I A, p. 300. McKinnon and Luckman Sinar note that "Sungei Mati," or "Dead River," is a quite common place-name along the east coast of northern Sumatra; E. Edwards McKinnon and Tengku Luckman Sinar, "Kota China," p. 65, n. 2 .

23J. V. Mills, Ma Huan. Ying-yai Shêng-Zan (Cambridge: Cambridge University Press for the Hakluyt Society, 1970), pp. 114-15, 252. 
Indonesian archipelago. ${ }^{4}$ One of them is $* \hat{A}-\imath j i-k \dot{z} \breve{e} t .25$ The glottal stop is an initial one and can be ignored. The transcription seems to resemble Tome Pires' "Arcat" or "Arqat." Pires, writing in the early sixteenth century, states that to the south of Aru was Arcat, bounded on its south by Yrcan (Rokan). 26

Two general observations can be made as a result of this perhaps rather trivial discussion of the meaning of Shêng-têng.

First, provided that my identification of the name with the Placuna molluscs is acceptable, the inference is that the coast in question was sufficiently well known in the trading world of the eighth century for its nickname to reach Chinese ears. The coast was far from being anonymous, and I readily admit that my previous description of it as being among the "isolated coasts" of Sumatra in early times 27 is an inapt one and is already being contradicted by the current archaeological research of $\mathrm{Mr}$. McKinnon and Tengku Luckman Sinar S.H. These scho1ars are unearthing a number of coastal sites in northeastern Sumatra which were by no means isolated from the outside world. Perhaps one day the origins of the Aru kingdom, first mentioned by that name in the Yüan-shih under the date of 1282,28 will be discovered to be much earlier than the thirteenth century. The site of the ancient political center need not have been continuously affected by the advancing coastline that seems to have displaced trading centers in the Aru region. 29

${ }^{24}$ See Wolters, "Landfall on the Palembang Coast in Medieval Times," Indonesia, 20 (1975), p. 52, n. 199.

${ }^{25} \mathrm{H} \sin \mathrm{T}^{\prime}$ ang-shu, 222C, $6 \mathrm{a}$.

${ }^{26 \mathrm{~A}}$. Cortesão (ed. and trans.), The Suma Oriental of Tomé Pires: An Account of the East, from the Red Sea to Japon, Written in Malacca and India in 1512-1515, 2 vols. (London: Hakluyt Society 2nd ser. 89-90, 1944), I, pp. 148-49. The coastline south of the Medan-Deli area may have been much further inland in the period when the Arcat toponym was known to Pires; see maps 9 and 10 in Wolters, "Landfal1," pp. 19-20. Arcat contained a slave market. I have wondered whether the original name was "Akit" or "Akik," the Malay word, according to Burkill (Dictionary, II, p. 1896), for a "mangrove." Winstedt (Unabridged Malay-English Dictionary, p. 10) states that "Akik" or "'Akik" is the word for Helix richmondiana, a univalve mollusc. The Portuguese trilled $r$ and the $-l_{j i-}$, representing an $r$ in the Chinese word, make it difficult to justify the identifications unless the medieval Malays sounded an $r$ in these words. The population transcribed immediately after ${ }^{*} \hat{A}-l j i-k i \breve{e} t$ is ${ }^{*} \hat{A}-l j i-d \hat{z}{ }^{\prime} i a$, which suggests a Chinese transcription of the place rendered by Ibn Rosteh as "Harladj"; G. Ferrand, Relations de voyages et textes géographiques arabes, persans et turks relatifs à l'Extrême-Orient du VIIIe au XVIIIe siècles (Paris: E. Leroux, 1913), I , p. 79. Harladj was an "island," whose governor was the head of the Mahărăja [of Srívijaya's] army.

27Wolters, Early Indonesian Commerce, chapter 12.

${ }^{28}$ Yüan-shih (Po-na edition; Shanghai: Commercial Press, 1935), ch. 12, 11a.

${ }^{29}$ In their report on the Kota China site in the Deli hinterland, Mr. McKinnon and Tengku Luckman Sinar write; "Observations at this site and others between Kuala Percut to the south and Stabat on the Sungei Wampu to the north would suggest that over a long period of time occupation diffused laterally rather than built up on one site. Thus as one river channel tended to silt up, making direct access to the sea difficult, the occupants moved downstream to deeper water and reestablished themselves on new sites, leaving a succession of earlier harbors on the banks of what 
Pires, when he refers to the Aru's ruler's residence "in the hinterland," may have been describing a very old geographical relationship between an inland capital and the port. 30

Second, historians of early Sumatra have reasons for being grateful to the molluscs and to shellfish in general, even if the molluscs have not found immortality in the Hsin T'ang-shu. Beach ridges, formed by severe storms and containing washed up shellfish, provide valuable indications for plotting and dating ancient coastlines in a region that has seen significant geomorphological change over the centuries. Moreover, shel1 mounds were sometimes used as foundations for houses and may conceal domestic utensils. Beach ridges and shell mounds are less valuable for reconstructing coastal change through silting than samples of the soil brought to the surface by corers, yet, in my present opinion, they still provide more useful evidence for recovering the realities of early Sumatran history than is found in Chinese sources that are as capable of misleading as they are of fascinating students of the historical geography of Sumatra.

\section{Glossary of Chinese Characters}

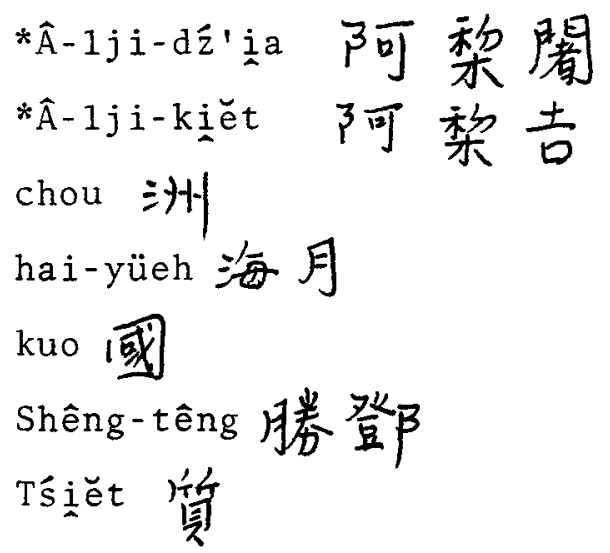

Calligraphy by Ms. Shan-hui Tu, Library Assistant in the Wason Collection of Cornell University Libraries.

are now minor streams." E. Edwards McKinnon and Tengku Luckman, "Kota China," p. 65. Somewhere in the historical experience of Malay coastal settlements, which were often influenced by geomorphological factors, may be part of the explanation of the development of a Malay historical tradition, which eschews temporal continuities and in which "layers of time never intrude on one another." Shelly Errington, "A Study of Genre: Meaning and Form in the Malay Hikayat Hang Tuah" (Ph.D. dissertation, Cornell University, 1975), p. 52.

${ }^{30}$ Cortesao (ed.), The Suma Oriental, I, p. 147. "He [the ruler] is a Moor and lives in the hinterland, and has many rivers in his country. The land in itself is marshy and cannot be penetrated." 
